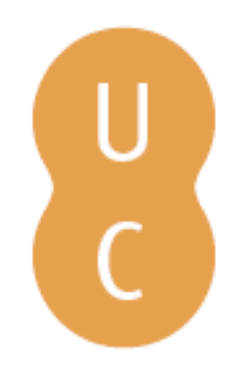

\title{
nombalina
}

\section{Fred Vondracek's Pattern of Life Span Development}

Autor(es): $\quad$ Ford, Donald $\mathrm{H}$.

Publicado por: Imprensa da Universidade de Coimbra

URL

persistente: URI:http://hdl.handle.net/10316.2/43648

DOI: $\quad$ DOI:https://doi.org/10.14195/978-989-26-1451-9_1

Accessed : $\quad$ 26-Apr-2023 12:59:54

A navegação consulta e descarregamento dos títulos inseridos nas Bibliotecas Digitais UC Digitalis, UC Pombalina e UC Impactum, pressupõem a aceitação plena e sem reservas dos Termos e Condições de Uso destas Bibliotecas Digitais, disponíveis em https://digitalis.uc.pt/pt-pt/termos.

Conforme exposto nos referidos Termos e Condições de Uso, o descarregamento de títulos de acesso restrito requer uma licença válida de autorização devendo o utilizador aceder ao(s) documento(s) a partir de um endereço de IP da instituição detentora da supramencionada licença.

Ao utilizador é apenas permitido o descarregamento para uso pessoal, pelo que o emprego do(s) título(s) descarregado(s) para outro fim, designadamente comercial, carece de autorização do respetivo autor ou editor da obra.

Na medida em que todas as obras da UC Digitalis se encontram protegidas pelo Código do Direito de Autor e Direitos Conexos e demais legislação aplicável, toda a cópia, parcial ou total, deste documento, nos casos em que é legalmente admitida, deverá conter ou fazer-se acompanhar por este aviso.

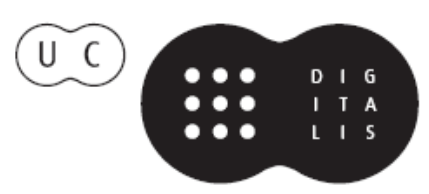


JOAQUIM ARMANDO FERREIRA MATTHIAS REITZLE

EDUARDO SANTOS (EDS.)

\section{CAREER \\ DEVELOPMENT \\ IN CONTEXT}

FESTSCHRIFT FOR

FRED VONDRACEK 


\title{
FREDVONDRACEK'S PATTERN OF LIFE SPA N D EVELOPMENT
}

Donald H. Ford, Penn State University, USA, donaldhford@gmail.com https://doi.org/10.14195/978-989-26-1451-9_1

\begin{abstract}
This chapter uses Fred Vondracek's Living systems theory of vocational behavior and development to analyze how his personal lifespan development helped shape his approach to education and work. Based on more than 50 years of common history at the Pennsylvania State University and Fred's accounts of his early family history during World War II and his immigration to the United States, Fred's career development from tile setter's apprentice to internationally recognized scholar and academic leader is examined. Evidence is presented to demonstrate how vocational development pathways emerge from creating, performing, and evaluating goal directed behaviors in varied contexts.
\end{abstract}

Keywords: Fred Vondracek, Living Systems Theory, Vocational behavior and development 


\section{Introduction}

Fred views individuals' effective performance of work roles as a cornerstone of both individual satisfaction and societal development. The primary goal of his scholarly work for the last third of a century has been to construct an evidence based theoretical model of the developmental dynamics of individuals' creation of their patterns of vocational behavior that would be sound and useful both for individual and societal development. He took his first major steps toward that goal in the 1980s.

A key guiding assumption was that each person always functioned as an integrated biological, psychological, behavioral and social entity in a specific situation, i.e., a person-in-context unit. That meant that a sound theory of vocational development needed to be multidisciplinary and fit with more general theory and knowledge about human development. He found such a theory in a book titled Humans as Self-Constructing Living Systems (D. Ford, 1987; 1994; 2014) that used the integrative and rapidly growing field of general systems theory, which is playing an increasingly powerful role in the natural sciences, as a framework for technological and medical advances, and for understanding human development and functioning as a person-in-context unit.

In 2014 Fred finally achieved his long term goal. His co-authored book, A Living Systems Theory of Vocational Behavior and Development (Vondracek, F.W., Ford, D.H., \& Porfeli, E.J.), merged all his previous work in that integrative framework. That book provides real life examples of how individuals' vocational development patterns can be understood using the living systems model, beginning with childhood experiences and continuing through development in the adult years.

This chapter uses Fred's new theory to analyze his personal lifespan development patterns. It reveals how his vocational 
life and scholarly accomplishments evolved and provides an interesting way to view his work. I will present Fred's story of his development and scholarly contributions in four time periods: 1941-1960; 1960-1969; 1969-2000; and 2000-the present.

The information and events described in this chapter come from Fred, friends, my memory and things written by him and others. I met Fred in 1965 when I appointed him as a graduate assistant in our psychological services program for Pennsylvania State University students and their families, called The Division of Counseling. Over the next 50 years our relationship evolved from student to colleague, co-author and friend.

\section{Childhood/Adolescence and Basic Education/Apprenticeship 1941-1960}

The guiding goal for the first part of Fred's life and for his family was survival in the context of war raging around them. Fred and his twin brother were born in 1941 just when Germany's success in WWII was nearing its peak. His father, Paul, had been drafted in the German army in 1940, and the

oldest son, Ernest, was drafted in 1944 (at age 16).

The family continued to live in their home in Sankt Augustin (near Bonn) until 1943 when the massive air attacks by the allies became so severe there that the German government evacuated his family - mother (Katharina) two sisters (Magdalene \& Marliese) and the 2 year old twins (Fred \& Hans) - east to Silesia, a safer part of the country. By February of 1945 that too became very dangerous because of Soviet advances from the east, and with the help of a kind neighbor, the family walked 12 miles to the nearest functioning train station to make their way to Thuringia in the central part of the country. 
Their journey took them through the city of Dresden, which they left riding on top of an overcrowded train on the night before Dresden was completely destroyed by means of massive firebombing by the allies.

When they arrived in Thuringia they had no food ration cards and consequently faced the very real prospect of starvation. Fred's older sister Marliese agreed to ride by bicycle to friends who lived in the relative safety of a farm in the Bavarian Alps to inquire whether they had room for the family. To her great relief, they agreed to shelter the family. Marliese then returned by bicycle to report the good news. On the way, she was strafed by a low-flying American plane. Luckily, she received only minor injuries and went on to get her family. They went by train and walked to Bavaria where they spent the remainder of the war. Ernest, Fred's oldest brother, abandoned his anti-aircraft unit when the war was ending, and joined the family in Bavaria.

In April of 1945 the war ended and Germany lay in ruins. There was no public transportation, food, clothing or other supplies. By August, Katharina decided it was time to take her family home to Sankt Augustin so they began that long walk. There were a lot of US army trucks on the roads, so sister Marliese (who was a very attractive young woman) invented a strategy. The family would hide at the side of the road while she stood on the road hoping some GIs would offer her a ride. When they did, Katharina led her family onto the road and they talked the GIs into giving all of them a ride. When they arrived home their apartment building was still standing but their apartment had been looted \& had suffered a lot of shrapnel damage.

Incredibly, on the very same day that they arrived, their father joined them. Paul had been a guard in a camp holding Russian prisoners of war in Finland. Because he treated the prisoners kindly and often helped them, they tipped him off 
when the Russian army was about to liberate the camp, urging him to flee. He and his friend left their posts and were guided through a series of safe houses through Finland into territory held by the British. Captured by the British, he was soon released to go home, aided in part by the fact that the Nazis had stamped all of his papers "politically unreliable" because he refused to join the Nazi party. He and his friend were the only survivors of the German soldiers guarding the Russian prisoners of war at the camp in Finland.

The family began restoring their home and their lives together. In the 1945-1948 post war period Germans were being punished by the victors. Anything that was manufactured, mined or grown in Germany was shipped to other countries as reparations. Fred remembers that experience. "I was hungry most of the time, although my parents did their best. There simply was no food available. I remember seeing worms in the flour and bread my mother could occasionally get from the store and maggots were often present in what little meat we could get. I remember having almost nothing but turnips for weeks at a time. Harvest season for potatoes and grains was a good time. The entire village would descend on the fields once they were declared 'free' (i.e., after the farmer had completed harvesting) and start to dig for any remaining potatoes and collect any remaining grain. Hans and I made it a game to see who could find the most food. People staked claims to parts of a field and dug as fast as they could; some hit it big, others went home empty- handed. In 1948 the United States began to implement its 'Marshall Plan' which provided resources to help Germany's transition to a more normal way of life."

(How did those first 7 years of his life affect Fred's development? He experienced how the contexts in which he lived shaped his life. During the war it could determine where and 
how he lived, and it could kill him. He developed confidence in his capabilities to do what was necessary even in the severest of living conditions, and didn't become fearful about tackling difficult tasks. He also learned, through the way his family shared solving their problems, the value and skill of being able to work cooperatively with other people to get things done.)

As the struggle for survival eased, life began focusing on working toward a better future. Marliese was the first to leave the family. She completed her training as a nurse, worked as a nurse briefly, and then married an American GI and moved back to the US with him where she worked as a nurse.

Hans and Fred's formal schooling started in 1948 in a bomb-damaged rural school. Each classroom had as many as 60 students. One teacher was responsible for teaching all subjects for the first four grades and another was responsible for grades five through eight. There were virtually no books or other materials. School facilities and resources improved slowly.

At that time in Germany the completion of $4^{\text {th }}$ grade public schooling was a key decision point in one's education. Students could either continue their basic education to prepare for work, or their parents could enable them to transfer to the Gymnasium whose completion would provide a graduate automatic admissibility to any German University. Entrance to a university was impossible without that. Fred was considered one of the best students in his basic school, but his parents didn't have money to send him to the Gymnasium. Fred's father distrusted educated people whom he thought often treated lower-class people "like crap" and did not want his children to become like that. Fred was very disappointed to miss that advanced education.

(The seeds of Fred's lifelong hunger for higher education and the personal independence it could provide were thus planted during his impoverished grade school years.) 
Fred found basic education to be easy and not challenging. To challenge himself he turned to sports competitions. Fred was the top athlete in his school, received the highest scores in his school district and three Presidential citations. He completed his basic education in the $8^{\text {th }}$ grade. Because of Fred's physical prowess, his father decided that Fred, rather than his smaller twin brother, should follow in his footsteps and learn to be a tile-setter (the highest paid and in high demand skilled labor in Germany at the time). Thus, at age 14, Fred began his adult work career by working as an apprentice with his father.

(Treating a young adolescent as an adult has a long history. For example, in my father's generation in the US graduation from the $8^{\text {th }}$ grade was the end of formal education for most people. At age 14 he became a cowboy in western Kansas and could walk into a saloon and get a drink like any adult.)

The working conditions were terrible as Fred described it. "We had no protective clothing. It was not uncommon to wear the same clothes at work for a whole week or even longer. Everything was done by hand with no power tools or equipment. The heaviest labor was assigned to the apprentice. For example, I had to unload and handle $50 \mathrm{~kg}$ bags of cement (I only weighed 135 pounds at the time). The official work week was 48 hours but I often had to work 7 days a week. My father took what I earned to help support the family, acquire a building lot, and build a house. I did admire my father's accomplishments considering the fact that he started with absolutely nothing at the end of WWII. Nevertheless, I envied my friends who went to the Gymnasium. They did no heavy physical labor, were not dirty, cold, bored-to-death with what they were doing, enjoyed interesting classes, played tennis and dated girls. I knew I could have done as well as they did in school but had to follow the pathway my father created for me." 
Fred and his brother began looking for other ways they might improve their future possibilities. They found the Berufsaufbauschule in Bonn (translated, quite literally, as 'occupational advancement school') could serve their purposes. It advanced students' capabilities beyond the 'Volksschule' (i.e., the 'people's school'). Fred explained "It would prepare me for the engineering program of a technical college. I knew I didn't want to be an engineer but I enrolled anyway, figuring that somehow I would find a way to use it to my advantage. Key subjects were mathematics, physics, German, a little English and chemistry. After work, I bicycled six miles to Bonn four nights a week for classes from 6:30pm to 9:30pm."

After three years of successful apprenticeship Fred advanced to the status of "journeyman" in his trade, enabling him to earn the same performance based wages his father earned. He turned 18 and then proposed to his father that he be allowed to go to school full-time and pay for his room and board at home with money he could earn by freelancing in his trade. His father rejected his proposal.

(By this time Fred had become a skilled adult worker in his first vocation. He learned the importance and value of careful planning and working hard to accomplish the goals to which he committed himself even when the work was not something he enjoyed. He also learned that, as in his early childhood, his life was largely being controlled by the demands and limitations of his contexts, particularly his father. He hated not being able to control his own life.)

Fred decided that if he was ever to get an advanced education and to do the kind of work he would like he would have to get away from his father's control by modifying his current context or moving to a different one. He began exploring possibilities (e.g., England; North Africa) but there were major 
problems with each. He then wrote to his sister, Marliese, in the US asking if she would allow him to come for a visit and she promptly agreed.

After several months Fred earned enough money "moonlighting" after his regular job to obtain a visitor's visa, the necessary vaccinations, and a one way ticket on a passenger liner from Rotterdam to New York. Fred then told his parents of his plans. His father disagreed strongly and told Fred he couldn't leave until he finished all the work his father assigned. Fred worked virtually day and night during his last days in Germany to complete that work demand. Literally hours before his scheduled departure, he went home, packed a small suitcase, said good bye to his mother, and boarded a train to Rotterdam. A friend joined Fred for the train ride because "it wasn't right for him to leave alone".

Fred boarded the "New Amsterdam" of the Holland America Line, which was built as a luxury liner before WWII, converted to a troop carrier during the war, and refitted as a passenger liner after the war. He shared the least expensive cabin on the ship (next to the engine room) with two other men. As the ship pulled away from where he had lived for the first 19 years of his life Fred felt in control of his life for the first time. He didn't know what the future held for him but he knew it would be his own creation.

Education and Training in America: BS, MS, Ph.D., and post doc 1960-1969

Fred was filled with anticipation and excitement as he sailed toward his new home. The beauty of the Atlantic Ocean was a new, awe inspiring experience as was the major storm that 
delayed their arrival in New York for two days. His imagination about the possibilities for his new life excited him, but he worried about the difficulties his limited English might create for him when he arrived in America. That concern eased when a nice German couple who were fellow passengers, and had lived several years in Canada, told him what it was like.

Fred arrived in New York on December 1, 1960. His new friends helped him find the Greyhound Bus station and buy a ticket to the small town of Welch, located in the coal fields of Southern West Virginia where his sister lived. Fred had \$19 left in his pocket.

He arrived in Welch after 18 hours of experiencing New York, New Jersey, Maryland, and Virginia. His excitement grew as his taxi approached his sister's home but she was not there! Fred knew she worked full time as an operating room nurse, so he settled down to wait. When she arrived she welcomed Fred with open arms despite the fact she was already caring for a husband and 4 children between 6 and 12 year old. That evening Fred got acquainted with Marliese's family and explained that he hoped to get a job, make his way in the US, and graduate from college. She said she would provide board and room and help him get started.

(By this time Fred had committed himself to three major long term goals: support himself, graduate from college, and make his way in the US. He now had to figure out how to accomplish them.)

Marliese began introducing Fred to people who needed tile work and surprisingly soon he was profiting from his hard earned craftsmanship skills and had an income base to build on. Marliese also arranged for Fred to attend some local high school classes, primarily to help him improve his very limited English skills. He ended up making some friends and being well accepted by his peers and the community. Fred began to feel like he belonged. 
One of the most pressing tasks for Fred was to seek a permanent visa. Finally, he got a green card through his sister's sponsorship. That summer he decided he was ready to pursue his dream of going to college. His sister had also longed to obtain a college degree, something she was unable to accomplish in Germany. They decided to enroll together at nearby Concord College (now Concord University). The College required a high school diploma for admission, which Fred didn't have. He decided to "bluff" his way in. He gave the admissions officer a certificate from his eight years of basic school printed in German. It worked. The admissions officer couldn't read German but decided to accept it and admitted Fred and his sister as freshmen in the fall semester of 1961. He majored in history and she in chemistry.

Marliese worked as the College night nurse to support her studies. She graduated as valedictorian of her class, became Director of Nursing at a local hospital, then a hospital administrator, and completed her career as a highly successful executive in charge of dozens of hospitals located on six continents. Fred supported himself throughout college by using his tile-setting skills to find work for weekends and semester breaks. He also received a scholarship from Concord that covered about half his tuition for the last two years. He graduated free of debt.

Fred described the experience: "I experienced those college years as nothing short of a vacation from real work. My first semester was something of a struggle because of my English limitations but I squeaked by. In my second year I took advanced English composition and was the only student to get an ' $\mathrm{A}$ ' in the course. I was active in student government and served as chief justice of the student disciplinary court. I carefully planned my academic program to speed up my progress by taking the maximum course load (and sometimes more), and took correspondence courses in the summer when I had to work. 
I earned 12 foreign language credits by examination. The Dean said I couldn't use German as a foreign language because that was my native language. So I said OK, I will use English as my foreign language. He rejected that too. After a little debate he let me use German."

Living his dream of going to college gave Fred great pleasure. But, as he approached his senior year he realized he had given little thought to how his college major might prepare him for a career. His history major would provide few possibilities. He had enjoyed his few psychology courses, and after some reading about job possibilities in psychology he concluded that this was a field with a good future. He succeeded in changing his major to psychology by taking a heavy load of psychology courses in his final year. Careful planning enabled Fred to complete his BS degree in less than three years, i.e. spring of 1964.

(Fred not only enjoyed his first experience of being in charge of his own life, but became confident of his capabilities for doing so effectively. He further strengthened his skills for using careful planning and disciplined hard work to accomplish bis goals. He developed skills for effectively relating to others to help achieve his goals in contrast with struggling with his father to overcome his opposition to Fred's goals. Perhaps most importantly, he learned to think of contexts as dynamic organizations of possibilities and limitations that can be interpreted and used in different ways for different purposes. For example, when thinking about the relationship of his academic studies to his career development, he realized his history major had limited possibilities. After reading and thinking about alternate possibilities he recognized the potential value of studying psychology, and he changed his major by taking a heavy load of psychology courses in his senior year. Later in his career he learned that recognizing a new potential utility of some 
existing component of his context created what was called a Contextual Affordance.)

There was never any question in Fred's mind about what he would do when he completed his Bachelors Degree. He was going to graduate school to obtain a Ph.D. A key motivation for this decision was his father always telling him not only what to do but how to do it. Fred wanted to control his own work and life. He vowed to advance to a level of expertise that would protect him from that kind of control of his work by others. An advanced education was the only way he could accomplish that goal since he wasn't wealthy. Fred chose the Pennsylvania State University for his graduate study because of its reputation in psychology and because he was offered a Public Health Service fellowship to finance his first year.

(Fred learned later that once again his context facilitated his plans because he was probably offered that fellowship because one of his Concord psychology professors was a friend of the head of Penn State's clinical psychology program to whom he privately recommended Fred. Fred carefully planned his program so be could finish his Ph.D. in four years. He became a naturalized US citizen in 1967 and was awarded his Ph.D. in 1968 , less than 8 years after he arrived in the US. He realized how leaving his home to live in the US transformed his developmental pathway. Fred couldn't have achieved that goal had he stayed in Germany.)

One aspect of Fred's Ph.D. training turned out to have a huge impact on his career and life, so I will describe it in more detail. Penn State had a unique, integrated psychological services program for its students and families. The first part was created in 1949 when there were lots of ex-GIs trying to get used to being back in college after WWII. Then at Penn State if an undergraduate failed in their courses they were 
automatically flunked out. A distinguished psychology professor convinced the University that most Penn State students who failed did so not because they weren't smart enough but because they had some kind of difficulties that could be corrected (e.g., family, financial, emotional, being in a major that didn't fit their talents).

A program was created so that instead of automatically dismissing such students they were referred to a Division of Intermediate Registration where specially trained counselors could help each student establish clear goals and develop the means to achieve them. This approach focused on how to facilitate each student's success by helping them construct a developmental pathway which focused on each student's capabilities rather than their limitations. It worked. About $80 \%$ of those "flunkers" recovered, returned to a regular major, and graduated.

Then that same professor argued that since we knew what kinds of things caused students to fail, why not develop a program that could prevent failures in the first place. The existing program was elaborated to do that and was renamed The Division of Counseling. Each entering freshman provided information about their interests, talents, educational history and other relevant factors. Then they and their parents (because families provide a key context for students' development) came to campus for a day to discuss all that information and how it fit with the student's plans. Students and parents first met separately with counselors so that family disagreements could be uncovered and then later they met together with a counselor to confirm or consider making changes in plans. At any time while they were at Penn State, any student who became dissatisfied with their major could enroll as a Division of Counseling student to help them develop a satisfactory plan. The rate of student difficulties dropped significantly. 
I was responsible for the Division of Counseling (DOC) program and used it to help train Ph.D. students in clinical and counseling psychology by providing paid graduate assistantships as a form of pre-doctoral internship for them. Fred was selected for one of those assistantships in his second year. One key objective was to help the graduate assistants learn how to apply the theoretical knowledge about human development they were studying in their graduate courses in helping undergraduate students deal with their developmental concerns and possibilities. Each student had a full time member of the professional staff as their training consultant. In addition, there were regular staff meetings in which relevant theory and case examples and academic procedures were examined and evaluated. I appointed Hugh Urban as coordinator of these training activities because he was a brilliant theorist, diagnostician, counselor and teacher.

Hugh served as Fred's training consultant. Here are some of Fred's evaluations of that experience. "This was a wonderful experience. We were treated as competent professionals. Each of us participated as student and family counselors for the entering freshmen program. During the year each of us was assigned counseling responsibility for $30+$ students who chose to register in DOC for an exploratory period. We also served as counselors for students who walked in the door any time seeking help. We had to work with all kinds of human development issues, e.g., how to select career goals and work effectively towards them; how to help students problem solve about their concerns; how to deal with problems in their friendships, family and love life; how to recover from a bad start in their major; how to break bad disruptive habits. While working there I learned a great deal about how university undergraduate education worked. 
I was very lucky to have Hugh as my supervisor. I was attracted to his intellect and to his openness to ideas and to sharing his knowledge and experience. We discussed the work he and Don Ford were doing in a comparative analysis of theories of psychotherapy. He introduced me to a new theory emerging in the natural sciences and engineering called general systems theory. He also arranged for me to experience conducting the counseling experience with a group of 60 parents. He was a very skillful, theoretically based diagnostician and counselor. I loved his case examples and learned a lot from him. Here is one he presented in a staff meeting:

'A young woman came to DOC for help because she was failing. I learned she had also been struggling for some time with an enduring depressive state. Theoretically, emotional states (e.g., anger; depression; pleasure) are activated as part of some current experiences, and fade away as the activating pattern ends unless the pattern is continued (like a fly wheel slows down and stops unless one keeps giving it a push). The place to start is to look for the conditions present when the depression began and then to look for conditions that keep it going.

This young lady often became very angry about her older brother whom she felt frequently received special attention from her parents while they neglected her. One day she became so upset about that pattern she angrily yelled to herself ' $I$ wish he was dead!' That night she received a telephone call telling her the brother had been killed in an automobile accident that day. She felt responsible. That triggered her continuous depressive state that had been going on for weeks. After several discussions we uncovered why she was unable to ease her depression. Every evening she lay on her bed with pictures of her brother, gifts and letters from him and thoughts about how terrible she had been to him. She kept her depression going 
by using that ritual to punish herself, keep her guilt alive and to keep her "depression flywheel" going.

She agreed to discontinue that ritual and replace it with one that would activate positive thoughts and feelings. As the depression faded away so did her academic difficulties. We then discussed her anger and guilt about their relationship to help her gain control of those troublesome thoughts and emotions."

(Fred's DOC experiences, with guidance from Hugh, helped Fred understand how the psychological theories he was studying in bis graduate classes related to the real life issues his counseling clients discussed with him. He learned to understand the critical role family contexts often play in a young person's personal and professional development. Because he worked with students majoring in all the colleges at Penn State, Fred learned a great deal about the nature and organization of undergraduate education and gained an in depth understanding of the diversity of vocational developmental pathways each kind of major provided students and the kinds of capabilities and interests each of them required. He was also impressed with the ways peoples' personal lives influenced their performance in their major/vocational pathway. His confidence in his professional capabilities was greatly strengthened.)

\section{9-2000 Building Academic/Research Programs and a Career at Penn State}

After graduation in 1968 Fred took a post-doctoral internship in the Veterans Administration health care program and began looking for a job. During his internship he evaluated job offers from places as diverse as the Ridgway Mental Health Center, the University of Kentucky, Lafayette College, and the Veterans Administration, which offered him a position as director of 
research at a very large psychiatric hospital. He struggled to decide which would be the best opportunity for beginning his professional career.

A great opportunity arose from a decision made by Penn State University a couple of years earlier: Penn State had decided to create a new kind of professional college called The College of Health and Human Development. I was appointed Dean to create the new college. It was assumed that the human issues that were its focus could not be understood and dealt with by single disciplines, making collaboration among disciplines necessary. Therefore, four multidisciplinary academic divisions were planned, including Biological Health, Individual and Family Studies, Community Development, and Man-Environment Relations. In addition, an Institute for Human Development was created to facilitate collaborative research. I appointed Hugh Urban to create the Division of Individual and Family Studies and he promptly offered Fred an appointment as Assistant Professor of Human Development.

Being part of that new visionary college was like being a kid in a candy store for Fred. It fit his personal goals and professional preparation beautifully. He was surrounded by creative colleagues whose primary commitment was to the promotion of human development rather than to elaboration of a discipline, and who were open to collaborative research to achieve that goal. As a professional college it focused not only on the elaboration of knowledge but also on how to apply sound theory and methods to improving people's lives. Since it was still being created, Fred had the opportunity to participate in the selection of its new faculty, and to help design and implement its undergraduate and graduate programs.

Perhaps most importantly the new college had a fundamental focus on the processes that guide construction of peoples' 
lives symbolized by the word development. Beginning in the late 1800 s the study of those processes was the domain of what was called learning theory. For two- thirds of a century the primary focus of learning theory was on how aspects of a person's contexts shaped what they learned. Those processes were called "conditioning" and "reinforcement." Many people rejected that theory because it described humans as reactive, mechanistic entities shaped by their contexts, sometimes called an outside-in view of human development. The influence of that theory peaked during the 1950s.

It has since been largely replaced by various other theories that shared the alternate assumption that people play a significant role in selecting what they learn, sometimes called inside-out theories, with labels like cognitive theory, information processing theory, and social context interaction theory. This theoretical shift was influenced by the emergence during the last half of the 20 century of three interrelated science and technology theories that have had a huge impact on human societies around the world: general systems theory, information theory and cybernetics. They provided a scientific basis for understanding humans as proactive, self-constructing entities rather than as reactive entities in their contextual interactions and they explained how complex organizations (like a person) can be self-organizing. The concept of Human Development clearly represented that emerging view and that is why the new college was named Health and Human Development.

(This developmental processes idea was a beautiful fit for the patterns of personal, educational and professional beliefs, knowledge, skills and professional experience Fred had constructed during the first 29 years of his life. Faculty colleagues who were hired to create academic and research programs in the new college illustrated how powerful an influence a label can 
have for understanding something. In the 1960s the processes of change in older people was called aging. The implied meaning was that getting older meant progressive decline in competence. Those colleagues rejected that meaning and demonstrated with their research and that of others that many kinds of changes in people's adult years are very positive. To symbolize that positive view they named their program the study of life span development (instead of aging) to link developmental processes as occurring from infancy through old age. That became part of Fred's thinking, and within two decades that positive concept and label had become widely accepted around the world and influenced how older people were thought of and treated.)

Fred's letter of appointment in 1969 specified that he would be expected to teach a minimum of one course each term but his "initial primary responsibility" would involve heading up a task force within the Institute of Human Development to formulate and generate a research and development project focused upon the early detection of delinquency-prone patterns of young people and the development of alternative strategies for intervention and activity modification to cultivate non-delinquent developmental pathways in such groups.

Fred promptly obtained $\$ 190,000$ funding from the Governor's Justice Commission and the Pennsylvania Justice Planning Board from 1971-74 for that project. That first research team of his included Fred, Hugh Urban and Bill Parsonage (a professor in the administration of justice program). Together, they developed and validated a diagnostic program for predicting the probability of a juvenile developing a delinquent pathway, created a Computer Assisted Regional Evaluation System for Juveniles using that program, and developed a Mobile Delinquency Service Center for three central Pennsylvania Probation Offices to implement it. Considering the primitive state of computer 
development in 1970, it is astonishing what they accomplished. Although the program worked well and was liked by the users, its use could not be continued because computers were so expensive at that time.

During that same decade Fred collaborated with other colleague teams on various kinds of projects focused on developmental issues at different ages: e.g., television content and children's behavior; life span behavioral development and the family; non-verbal techniques for assessing frustration responses in pre-school children; enhancing field experiences for baccalaureate level careers in adult development and aging; interventions within individual and family development; and dysfunctions in development.

But in that first decade of Fred's career research was not where his heart was. "In that early stage of my career my goals and efforts were devoted first and foremost to help establish a world-class, best of its kind undergraduate program, providing leadership designed to instill a culture of interdisciplinary collaboration among the faculty, and helping to recruit and retain faculty who could thrive in such a context. In his earlier life, Fred became skillful at identifying goals to be accomplished and seeing that they were done well. Therefore, it is not surprising that the first two directors of the Division of Individual and Family Studies (IFS), Hugh Urban and Paul Baltes, used Fred as their "administrative right hand" in various leadership roles with a key emphasis on developing and implementing the new IFS undergraduate major.

Fred's Division of Counseling experiences in helping students succeed in diverse majors was invaluable to him in avoiding faulty curriculum designs and creating interesting programs. For example, each student had to spend a semester working in some human development program of their choice and in 
writing a paper about how that program worked and how it might be improved. Such "work experience" opened up job possibilities for lots of students. Over several decades the IFS major (renamed the Human Development and Family Studies HDFS major) was also offered on several Penn State branch campuses and became one of the largest undergraduate majors at Penn State. When Paul Baltes left in 1978 to assume a major academic role in Germany, Fred was asked by the faculty to serve as the HDFS Director.

(As Fred approached his $40^{\text {th }}$ birthday be reviewed his first 11 years as a faculty member at Penn State. He had taught one or more courses every semester and had been continually involved in some research project, usually with collaborators. He had published over a dozen papers and book chapters. Thus, his academic career was respectable but not impressive. That was because performing in various administrative roles to belp create and implement the new college had dominated bis time and attention.

The first phase of creating the College was now completed, and so Fred decided it was time to change the primary focus of his thoughts, time and energy to teaching and scholarly work aimed at cultivating his personal career and ideas about ways of facilitating positive developmental pathways for people. He wanted a focus that could encompass a person's development from childhood to old age. He decided that since work plays such a fundamentally important role in people's lives be would focus on vocational development. His guiding idea was to try to merge his extensive knowledge derived from his rich personal and professional experience and the competencies of creative colleagues concerning human development into an integrative and practically useful model for understanding a person's vocational and career development across their life span. So 
after three years of serving as IFS division director be resigned and started down that new pathway.)

Several basic assumptions concerning the nature of human development had evolved from Fred's 40 years of diverse personal and professional experience and his interactions with creative colleagues' ideas about human development. The first step in his new pathway was to evaluate and elaborate those ideas.

Fred and his colleague Richard Lerner shared similar views about the nature of human development. When Rich learned of Fred's plans he suggested they collaborate in writing a chapter for a new Handbook of Developmental Psychology, Vocational Role Development in Adolescence (Vondracek, F. W., \& Lerner, R.M., 1982). They were pleased with the results and decided to extend their collaboration in a paper for the Journal of Vocational Behavior. Fred initiated a practice he continued throughout his career by inviting one of his doctoral students to collaborate in writing The Concept of Development in Vocational Theory and Intervention (Vondracek, F. W., Lerner, R. M., \& Schulenberg, J. E., 1983).

Fred then proposed to his coauthors that they put all their ideas together in the form of a new theory in a book. The result was Career Development: A Life-Span Developmental Approach (Vondracek, F. W., Lerner, R. M., \& Schulenberg, J. E., 1986). In this book they asserted that the person-in-context is the basic dynamic unit to be understood and that this unit develops through probabilistic epigenetic processes. They emphasized that a person's behavior always occurs in some kind of context that provides the possibilities and constraints (sometimes called affordances), within which persons construct their activities and vocational pathways. They called this developmental contextualism.

With the concept of embeddedness they emphasized that key phenomena of human life exist at multiple levels of organization, 
but because they do not operate independently of one another they operate through dynamic interaction. This makes possible plasticity in development and enables a person to function as producer of their own development. These developmental processes operate at all ages, which means that the construction of different vocational pathways can begin in childhood and occur at any age, requiring a life span developmental approach.

They illustrated their theory with ways developmental processes were manifest in the lives of adolescents and women, and then described ways of influencing vocational development. They also did something no other theory of vocational development had done. They described implications of their theory for the design of research to study vocational development. They concluded that, since it is a person centered theory, classical research designs that focus on analyzing groups of people would not be appropriate. They illustrated the use of cutting edge research designs for studying person development that were being created by a colleague, John Nesselroade, and others (e.g., replicated single subject research designs).

Fred was surprised by the impact of their new theory. Leaders in the field praised its uniqueness and importance. His insistence on the importance of context in vocational development was so persuasive that many others in the field began emphasizing it in their work. Consequently, Fred became an admired and influential voice in the field of vocational and career development. Fred's 1986 book had a major impact on the field of vocational and career development, and the ideas about the basic nature of human development elaborated in the book guided Fred's scholarly activities through the rest of his career. The positive reception of that book encouraged Fred to continue work toward the creation of a comprehensive and useful theory of the nature of peoples' creation of their vocational and career 
pathways. I will not discuss Fred's scholarly work during that period because other colleagues of his during that period have provided chapters in this book.

I will note that Fred's work during that period culminated in his enjoying being known as a very productive and internationally recognized researcher and theoretician in his field. Scholars from other countries spent time as visitors at Penn State to work and collaborate with Fred. He has enjoyed extensive collaborations with scholars from the University of Coimbra in Portugal, he was a visiting scholar at Kansai University in Japan, and the Universities of Giessen and Jena in Germany, where he was supported by the German Academic Exchange Service (DAAD). As a youngster he had to leave Germany to get a University education elsewhere, so he chuckled with pleasure when the distinguished old German University of Jena (which would not have admitted him as a student in 1960 under any circumstances) gave him a seldom-used honor by conferring on him an honorary professorship in 1998. Fred didn't just visit universities, he collaborated in published scholarly work with colleagues at each of them.

Fred served on a number of editorial boards of scientific journals in the US and other countries, reviewed manuscripts for many journals and was an occasional reviewer for Canada Counsel and the Social Sciences and Humanities Research Counsel of Canada, the US-Israel Binational Science Foundation, German National Science Foundation, German Institute for Youth Research, and Swiss National Science Foundation.

Fred also continued to be very active in other faculty roles. Not only did he teach regularly and have graduate students, but he also served on over 20 college committees of all kinds. He was also elected to represent the faculty on Penn State's faculty senate and served on many committees there dealing with University concerns. 
He also maintained his ability to test his theories in real life circumstances by using his clinical and counseling skills to serve as a consulting psychologist to several community-based counseling, psychiatric and youth development programs.

(In this period Fred fulfilled his childhood dreams. He not only obtained the higher education he sought but helped create new educational programs and helped to provide such education to young men and women. He constructed a career in which he was in control of his life, deciding what he wanted to do and how to do it. His professional context enabled him to know and collaborate with other creative scholars and to help cultivate the scholarly development of young emerging scholars.)

\section{0-Present: College Administrative Leadership and Continued Scholarly Activity}

Beginning a new century, Fred was called on by a new Dean to again provide leadership for his College as Associate Dean for Undergraduate Programs and Outreach. Outreach was a new label for providing educational programs for the general adult population previously called Continuing Education. It was on the cusp of the creation of major new technology based programs and educational methods now called the Penn State World Campus.

Five years later that Dean left and Fred was appointed Interim Dean of the College of Health and Human Development. During his ten years of serving in the roles of associate or interim dean, research income and expenditures, undergraduate enrollments, and income from continuing education in the college were at the highest levels achieved in the history of the college. Existing and newly created physical space for the college were also at the highest level. When a new Dean was appointed, she asked 
Fred to serve as Senior Associate Dean to help her effectively implement the role of Dean. Despite his heavy administrative responsibilities in a college whose scope and size exceeded those of many small universities, Fred continued to mentor graduate students and stay involved with his foreign colleagues.

Then the tide of his life changed. In 2009 Fred was diagnosed with a rare, life threatening form of blood cancer. Treatment of it had serious side effects, e.g. produced periodic uncontrolled bleeding; "killed" his immune system. To protect himself from potentially dangerous contexts from which his immune system couldn't defend him he drastically altered his life style, e.g., he reduced his involvements with others, altered his diet, and discontinued travel. He continued his involvements with his graduate students and colleagues which could be done safely with modern technologies. A treatment pattern was finally created that progressively succeeded in maintaining a steady state pattern that enabled him to live comfortably with his illness and limitations. I knew he had reached that point when he allowed himself to have a beer now and then, a "quality of life" necessity for a good German-American like Fred.

(Fred knew complete recovery from his illness would either take a long time or only reach a steady state enabling bim to manage living with it. So he retired from all his formal academic and administrative roles and activities, but not from his long standing vocational pathway. Person and context changes often require changes in a person's pathways. He asked himself if he could devise a way of continuing that pathway within the limitations imposed by his illness, and he turned to a possibility he had occasionally thought about.)

For decades, Fred and I had similar scholarly goals. Fred's was to create a sound theory of vocational development. Beginning in my graduate school days I started searching for 
a sound, empirically based theory to guide psychotherapy and counseling. Thus, both of us had been working to create a theoretical model of aspects of human development.

At first I focused on learning theory. After a couple of years I realized that it's mechanistic, behaviorist nature didn't fit my emerging ideas about human development. Hugh Urban (another new PhD) and I shared that goal and formulated a different search strategy. We decided to do a comparative analysis of all theories of psychotherapy then available to see if we could find any underlying theoretical similarities. There was widespread interest in emerging psychotherapies at the time, so in 1963 we published the results in a book, Systems of Psychotherapy. It sold 40,000 copies and significantly influenced the development of that field). There was little agreement among psychotherapies so we decided to search theoretical models in other fields and found General Systems Theory, which was just emerging in the natural sciences. Hugh was Fred's mentor at the time and stimulated his interest in systems theory.

Hugh had a strong interest in psychopathology, so he decided to explore using systems theory to understand psychopathology (dysfunctional human development). I focused on using it to understand psychotherapy and positive human development. I quickly realized that it provided a basis for understanding all aspects of human development and began analyzing the scientific literature about all aspects of a person, i.e. the biological, psychological, behavioral and social person, to identify the system roles each component of a person performed. After I resigned as Dean I spent the next ten years to intensively complete that analysis and using general systems theory to synthesize those findings in an integrative theory of human development published as Humans as Self-Constructing Living Systems (D.H. Ford, 1987), only one year after Fred published his A Life Span 
Developmental Approach to Career Development. Five years later one of my sons used my theory to create a new theory of motivation processes: Motivating Humans: Goals, emotions and personal agency beliefs (M. Ford, 1992). Fred considers motivation a key factor in vocational development, so he used Martin's motivational systems theory and recommended it to colleagues who consulted him about their research.

Thus, we shared three theories that are focused on human development patterns and processes. The products of Fred's creative thought and scholarly work over a quarter of a century have been influential in identifying different kinds of developmental patterns manifest in different kinds of contexts and phases of life. But Fred considered his developmental pattern formulations limited because, although they emphasized the importance of developmental processes, they included no theoretical, empirically supported model of developmental processes that produce those patterns. Fred thought "Why not merge the three theories and create a new theory of vocational behavior development based on a sound theory of patterns of developmental processes that could guide practical applications?"

We discussed the idea and agreed that it was something we could both handle within our activity limitations (i.e., his illness and my heart problems). We promptly began working to merge his formulations of lifespan developmental contextualism with my self-constructing living systems theory, and my son Martin's motivational systems theory. Following Fred's long tradition, one of his former graduate students was invited to be a co-author.

The results were recently published as A Living Systems Theory of Vocational Behavior and Development (Vondracek, F.W., Ford, D.H., \& Porfeli, E. J., 2014). It explains how a person's vocational development pathways emerge from creating, performing and evaluating goal directed behavior episodes. That 
is the model used in writing this chapter to describe Fred's personal lifespan development.

Fred's health problems are now in a manageable steady state as illustrated by current activities. He recently drove to Florida by himself (he loves driving a good car) to visit his sister, Marliese. As I write this last paragraph he is flying to Europe to participate in the Society for Vocational Psychology meeting at the University of Coimbra in Portugal. What will Fred do next? The following excerpts from a letter he recently received from a distinguished American scholar of vocational development gives some hints of what may keep this creative scholar/professional engaged with his colleagues.

"Thank you for the copy of your new book. It is a landmark achievement that will influence and shape scholarship in vocational psychology for the next generation. It presents a grand statement of your work that will leave a lasting legacy. I read it in one sitting and that stimulated me to want to read it again more slowly. The propositional model is the gold in these pages. This is where the task lies, as you wrote we need to identify and organize the processes of self-construction. In the epilogue, you hope that your theory will serve as an organizing framework for use by future scholars. I am confident it will and I regret that I am too old to begin my own work using it as a starting point." (M. Savickas, May 25, 2014).

\section{References}

Ford, D. H. (1987) Humans as self-constructing living systems: A developmental perspective on behavior and personality. Hillsdale, NJ: Lawrence Erlbaum Associates.

Ford, M. E. (1992) Motivating humans: Goals, emotions, and personal agency beliefs. Newbury Park, CA: Sage Publications.

Savickas, M. (2014). Personal communication to Fred Vondracek, May 25, 2014. 
Vondracek, F. W. \& Lerner, R. M. (1982) Vocational role development in adolescence. In B. Wolman (Ed.), Handbook of developmental psychology. Englewood Cliffs, NJ: Prentice Hall.

Vondracek, F. W., Lerner, R. M. \& Schulenberg, J. E. (1983) The concept of development in vocational theory and intervention. Journal of Vocational Behavior, 23, 179-202.

Vondracek, F. W., Lerner, R. M. \& Schulenberg, J. E. (1986) Career development: A life-span developmental approach. Hillsdale, NJ: Erlbaum Associates.

Vondracek, F. W., Ford, D. H., \& Porfeli, E. J. (2014) A living systems theory of vocational behavior and development. Rotterdam: Sense Publishers. 